DOI: 10.17707/AgricultForest.65.2.02

\author{
Radmila BOJOVIĆ, Vera POPOVIĆ, \\ Snežana JANKOVIĆ, Vera RAJIČIĆ, \\ Jela IKANOVIĆ, Miloš REMIKOVIĆ and Divna SIMIĆ ${ }^{1}$
}

\title{
EFFECT OF GENOTYPE ON MORPHOLOGICAL AND QUALITY FEATURES OF SUGAR BEET
}

\begin{abstract}
SUMMARY
The importance of sugar beet is great because it gives root yield of about $50 \mathrm{t} \mathrm{ha}^{-1}$ and $30-40 \mathrm{t}$ of fresh leaves and heads of beet that is used for feeding cattle. In the Republic of Serbia are favorable agro-ecological and soil conditions for the production of sugar beet. In the structure of total arable land of the Republic of Serbia, sugar beet accounts for about $2 \%$ where $94 \%$ of it is in Vojvodina, which has the most favorable climate and soil conditions, tradition and proximity of capacities for root production and processing. In addition to its adaptability to climatic conditions, sugar beet reacting quickly to changes in meteorological factors which greatly affect root yield and sugar content.

In the three-year trials it was examined morphological characteristics and the amount of a-amino $\mathrm{N}$ in five genotype of sugar beet. According to the survey results, the largest number of leaves at the genotypes at technological maturity had the genotype Otis (35.33) while the smallest had had genotype Severina (15:53). Genotype Otis, as a whole, had the highest leaf area ( $\bar{X}=10193.13$ and Xmax $=11483.79$ ), and the lowest had genotype Severina $(\bar{X}=4242.33$; Xmin $=3982.44)$. The lowest average value of the amount of $\alpha$-amino $\mathrm{N}$ indicators were found for Chiara and Laetitia ( $\bar{X}=2.23$ ). The observed traits were largely depended on the genotypes and years. Genetic variation is necessary for successful breeding.
\end{abstract}

Keywords: sugar beet, genotype, morphological traits, $\alpha$-amino N.

\section{INTRODUCTION}

Sugar beet (Beta vulgaris L.) is dicotyls plant, belonging to the family Amaranthaceae. Although in the above genus are annual and biennial species, grown sugar beet is a biennial plant species. Genus Beta, is a member of the family Chenopodiaceae, which in the cultivated group comprises sugar beets

\footnotetext{
${ }^{1}$ Radmila Bojović, (corresponding author: radmilab@yahoo.com, bravera@eunet.rs), Jela Ikanović, University of Belgrade, Faculty of Agriculture, Nemanjina 6, Zemun Belgrade, SERBIA; Vera Popović, Institute of Field and Vegetable Crops, Maksima Gorkog 30, Novi Sad, SERBIA; Snežana Janković, Divna Simić, Institute for Science Application in Agriculture, Belgrade (IPN), Belgrade, SERBIA; Vera Rajičić, Center of Small Grains, Kovačević Save 31, Kragujevac, SERBIA; Miloš Remiković, University of Montenegro, Biotechnical faculty, Podgorica, MONTENEGRO;

Notes: The authors declare that they have no conflicts of interest. Authorship Form signed online.
} 
(Beta vulgaris saccharifera), fodder beets (Beta vulgaris crassa), leaf beets (Beta vulgaris cicla) and garden beets (Beta vulgaris rubra) (Ninfale and Angelino, 2013, Trifunovic et al. 2015).

Sugar beet leaf is simple and consists of leaf area and stem. The first leaves are much smaller than those that appear later. The stalk is thickened and ribbed. The first pair of opposite leaves emerges for 10 - 12 days after germination. Every 2 - 3 days appear over a new leaf which emerges at an angle of 135 to the previous one. The rosette leaves are spirally arranged and rosette itself can make 50 - 60 leaves and more. Leaves from 10th to 25th have the highest leaf area. Life of leaf runs from 27 to 70 days or more depending on the order of appearance, variety and production conditions. During the growing season leaves gradually die off. The stem is straight, ribbed, branches and grows up to $2 \mathrm{~m}$ and from the armpit leaves formed lateral branches of the first order, from which form the branches of the second order, and so on. In the axils of leaves branches last row formed flowers (in the second year of vegetation). Pollination is by insects. The fruit is coalesced groundnut (Glamočlija, 1990, Filipović et al. 2007, 2009).

Compared with some major field crops in Serbia, sugar beet production in the past has been characterized by the cultivating of both domestic and foreign varieties (Nenadic et al. 2003). In the Republic of Serbia are favorable agroecological and soil conditions for the production of sugar beet. In the structure of total arable land, sugar beet accounts for about $2 \%$. 94\% of the area under sugar beet is in Vojvodina, for its favorable climate and soil conditions, tradition and proximity of root processing capacities.

The proposed percentage relationship of sugar beet types in total sowed surface creates the possibility that the sugar beet gradually collecting from the fields and processing according to the technological maturing. Bojović (2014) suggest that such a combination of types provides a good digestion from the beginning of treatment and, at the same time, successive sowing of winter crops after removing of sugar beet.

The aim of this study was to investigate the influence of variety on the productive and morphological characteristics of sugar beet in agro-ecological conditions of South Banat.

\section{MATERIAL AND METHODS}

The study of the genotype influence on the morphological and technological characteristics of sugar beet was done in the period of 2007-2009. in agro-ecological conditions of South Banat at the experimental fields of the Institute Tamis PSS. Subjects of study were Otis, Chiara, Laetitia, Irina and Severina. Genotype Otis (producers Strube - Dickmann) is intended for removing the medium term. Genotypes Laetitia and Severina (producer KWS) recommended for removing medium terms. Genotype Chiara (producer KWS) is tolerant to drought conditions and is recommended for middle and later periods of extracting and NS genotype Irina (producer Institute of Field and Vegetable 
Crops in Novi Sad) has well balanced root yield and sugar content and recommended for later removing from fields. The experiment was a randomized block system with four replications. Preceding crop, in all three year, was wheat. Land treatment was in two stages (August and October). Seedbed preparation and seed sowing were done at the end of March. Care and protection of crops were standard. Soil type on which are experiment derived is carbonate chernozem formed on loess terrace with high natural fertility. In texture it is loam (Bojović et al. 2014). Samples for determining the aboveground biomass were taken at the experimental plots. To determine the technological value of sugar beet root all the samples taken from the experimental plots were prepared for chemical analysis in the laboratory of sugar factories AD Unity in Kovacica. Laboratory analysis determined the content of "harmful" - $\alpha$-amino nitrogen expressed in mmol / 1000S. The data were analyzed using the analytical statistical method STATISTICA 12 for Windows. The results are presented in tables and graphs.

\section{Meteorological data.}

In addition to the genotype and soil conditions, production technology and meteorological conditions have a great impact on the growth of plants (Djekic et al., 2017; Đekić et al., 2017; Živanović et al., 2017; Terzić et al., 2017; Ugrenović et al., 2018; Maksimović et al. 2018, Stevanović et al. 2018). One of the most important agro-technical measures in the sugar beet production is sowing. Proper sowing ensures optimal crop density and high yield. In our country, sowing of sugar beet usually is in the second half of March. Thermal conditions can then be unfavorable and unstable so it needs knowledge of seed and seedling traits in relation to possible adverse conditions in the soil at sowing time, seed germination and seedling emergence (Bojović, 2014).

Based on data Hydro-meteorological Station Pancevo monthly mean air temperatures are ranged from $18.00^{\circ} \mathrm{C}$ (in 2008) to $18.20^{\circ} \mathrm{C}$ in 2007 (Bojović et al. 2014). Thermal conditions during the study were $0.5{ }^{\circ} \mathrm{C}$ higher than the perennial average $\left(17.6{ }^{\circ} \mathrm{C}\right)$ and higher than the conditional-optimum requirements for plants $\left(15.3^{\circ} \mathrm{C}\right)$.

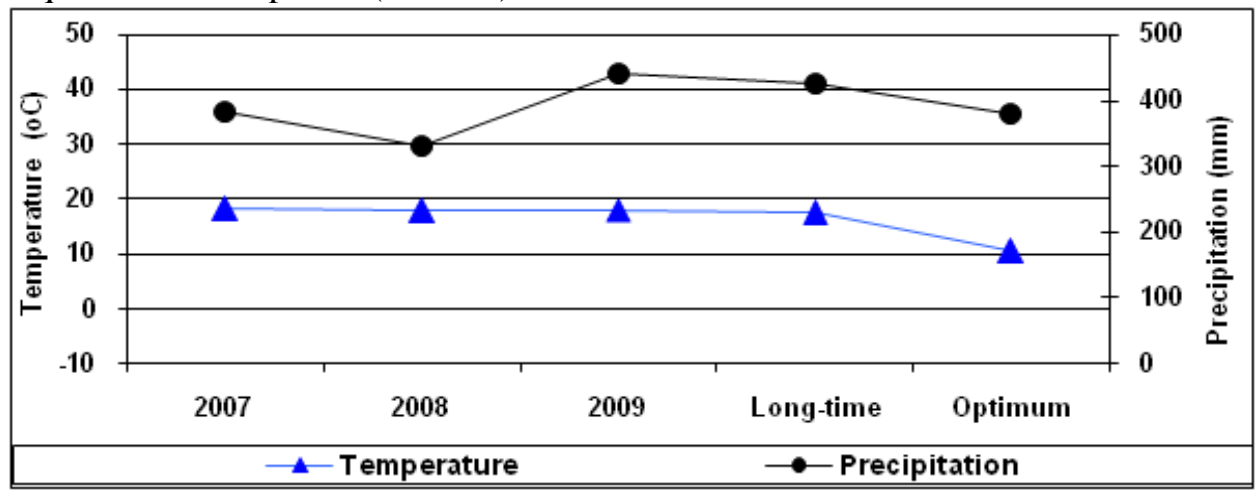

Graph. 1. Temperature, ${ }^{\circ} \mathrm{C}$, and precipitation, $\mathrm{mm}$, Pančevo, Serbia 
Total monthly rainfall had the great variation by years. Smallest total precipitation was in 2008 (331 mm), then in 2007 (384mm) and the highest in $2009(440 \mathrm{~mm})$. Total precipitation average during the growing season in the study period were lower by $41 \mathrm{~mm}$ compared to the multi-year average $(426 \mathrm{~mm})$ and at the level of conditionally-optimum requirements for plants $(380 \mathrm{~mm})$. Total rainfall during the growing season in 2007 were at the level of conditionally-optimal needs of plants, while in 2008 they were lower by $49 \mathrm{~mm}$, and in 2009 more by $60 \mathrm{~mm}$ compared to the level of conditionally-optimal needs of plants $(380 \mathrm{~mm})$ vegetation period (Graph.1).

\section{RESULTS AND DISCUSSION}

Number of leaves. According to the results, the highest average number of leaves in the technological maturity of the genotypes, had the genotype Otis (35.33), and the smallest had genotype Severina (15.53), Table 1.

Table 1. Descriptive statistics for the number of leaves of sugar beet genotypes

\begin{tabular}{lcccrrc}
\hline Genotype & $\mathrm{X}_{\min }$ & $\mathrm{X}_{\max }$ & $\bar{X}$ & $S_{\bar{x}}$ & $\mathrm{~S}$ & $\mathrm{Cv}(\%)$ \\
\hline Otis & 30.97 & 36.13 & 35.33 & 0.49 & 1.55 & 4.38 \\
Chiara & 27.00 & 27.70 & 27.29 & 0.06 & 0.19 & 0.72 \\
Laetitia & 16.77 & 18.50 & 17.47 & 0.17 & 0.55 & 3.13 \\
Irina & 22.77 & 23.37 & 23.05 & 0.06 & 0.20 & 0.88 \\
Severina & 14.70 & 16.17 & 15.53 & 0.13 & 0.40 & 2.58 \\
\hline
\end{tabular}

The variation of the average values of the number of leaves of sugar beet genotypes are expressed by the coefficient of variation and standard deviation. Analysis of the data was observed low variability where the greatest variation was in the genotype Otis $(\mathrm{CV}=4.38 \%)$ and the lowest in genotype Chiara $(\mathrm{CV}=$ $0.72 \%)$.

Leaf area. Variety Otis, as a whole, had the highest leaf area ( $\bar{X}=$ 10193.13 and $\mathrm{Xmax}=11483.79)$, and the lowest genotype Severina $(\bar{X}=$ 4242.33, $\mathrm{Xmin}=3982.44)$.

Table 2. Descriptive statistics of the studied genotypes of leaf area

\begin{tabular}{lcclccl}
\hline Genotype & \multicolumn{1}{c}{$\mathrm{X}_{\min }$} & \multicolumn{1}{c}{$\mathrm{X}_{\max }$} & \multicolumn{1}{c}{$\bar{X}$} & \multicolumn{1}{c}{$S_{\bar{x}}$} & $\mathrm{~S}$ & $\mathrm{Cv}(\%)$ \\
\hline Otis & 8471.68 & 11483.79 & 10193.13 & 237.89 & 752.26 & 7.38 \\
Chiara & $8135 ., 79$ & 9340.91 & 8579.29 & 127.94 & 404.59 & 4.72 \\
Laetitia & 5047.58 & 6376.05 & 5584.02 & 143.95 & 455.20 & 8.15 \\
Irina & 6056.21 & 6902.36 & 6410.64 & 75.50 & 238.75 & 3.72 \\
Severina & 3982.44 & 4426,29 & 4242.33 & 44.09 & 139.41 & 3.29 \\
\hline
\end{tabular}


The coefficient of variation, as a measure of dispersion, with this indicator ranged $3.29 \%<\mathrm{Cv}<8.15 \%$ which leads to the conclusion that it is a relatively low level of variation of this indicator within the genotype (Table 2).

The amount of $\alpha$-amino nitrogen content. Smallest average value of $\alpha$ amino $\mathrm{N}$ were at the genotypes Chiara and Laetitia $(\bar{X}=2.23)$. The largest amount of this indicator $(\bar{X}=5.88$ and $\mathrm{Xmax}=6.50$ ) had a genotype Irina. For other genotypes values digestion almost halved (tab. 3 ).

The dispersion of the observed indicators of the highest in the genotype Chiara $(\mathrm{Cv}=45.08 \%)$.

Table 3. Descriptive statistics for the amount of the $\alpha$-amino $N$ studied varieties

\begin{tabular}{lccrrrr}
\hline \multicolumn{1}{c}{ Variety } & $\mathrm{X}_{\min }$ & $\mathrm{X}_{\max }$ & $\bar{X}$ & $S_{\bar{x}}$ & $\mathrm{~S}$ & Cv (\%) \\
\hline Otis & 2.71 & 3.58 & 3.19 & 0.10 & 0.31 & 9.70 \\
Chiara & 1.47 & 4.53 & 2.23 & 0.32 & 1.00 & 45.08 \\
Laetitia & 1.59 & 2.93 & 2.23 & 0.14 & 0.44 & 19.93 \\
Irina & 5.27 & 6.50 & 5.88 & 0.14 & 0.43 & 7.41 \\
Severina & 2.10 & 3.22 & 2.59 & 0.13 & 0.42 & 16.17 \\
\hline
\end{tabular}

\section{Correlation between the studied parameters of sugar beet.}

Studied correlation indicators were expressed by Pearson's correlation coefficient. Among the indicators there is a weak dependence if $|0.00|<\mathrm{r}<|0.50|$, medium dependence if $|0.50|<\mathrm{r}<|0.75|$, dependence strong if $|0.75|<\mathrm{r}<|0.90|$ and very strong dependence if $|0.90|<\mathrm{r}<0.99 \mid$.

Correlation between the studied indicators individually for each genotype, are given in Table 4.

Based on the strength connections between the studied indicators, we can conclude that there was a correlation connection of all indicators, but of different intensities (tab. 4). Very strong positive correlation was between the number of leaves and leaf area $(\mathrm{r}=0.828)$ and between the leaf surface and $\alpha$ amino $\mathrm{N}(\mathrm{r}=$ 0.628) in average for all examined genotypes.

The observed traits largely depend on the genotypes. Genetic variation is necessary for successful breeding. In a breeding program it is therefore of utmost interest to quantify the variation among breeding lines and wild relatives of the crop (Ghasemi et al. 2014).

From sugar beet, beside the main products - sucrose, by various technological processes, from harvest residues obtained after processing we are getting a large number of different products. The heads and leaves that remain in the field, have great nutritional value as they contain 13\% dry matter, of which 
$6.8 \%$ BEM, $2.4 \%$ of total protein, $2.4 \%$ of mineral salts and $0.9 \%$ cellulose $0.5 \%$ of oil (Glamočlija, 1986). The yield and technological quality of roots were significantly associated with climatic conditions, soil (composition, structure and processing) and the most important agro agrotechnical measures, tillage, sowing, the correct choice of varieties, plant nutrition and crop protection. Size of root is in inverse proportion to the sugar content (Dobrovnaya et al, 2009, Bojović, 2014).

The great importance of the sugar beet is show in data that the yield of $50 \mathrm{t}$ ha $^{-1}$ of root gives 7 tons of sugar, 2.5 tons of dry noodles, 2 tons of molasses and $2.5 \mathrm{t}$ saturation sludge. Further processing of molasses it can be obtained 650 liters of alcohol or more than $1250 \mathrm{~kg}$ of yeast. There is also a $30-40 \mathrm{t}$ of fresh leaves and heads of beet for feeding cattle (Bojović et al. 2014).

Table 4. Correlation matrix parameters examined

\begin{tabular}{|c|c|c|c|}
\hline Indicators & $\begin{array}{c}\text { Number of } \\
\text { leaves }\end{array}$ & The leaf area & $\begin{array}{l}\text { The amount } \\
\text { of } \alpha \text { amino } \mathrm{N}\end{array}$ \\
\hline \multicolumn{4}{|c|}{ Correlation matrix for all examined genotypes } \\
\hline Number of leaves & 1 & $0.828 * *$ & $0.189^{\mathrm{ns}}$ \\
\hline The leaf area & - & 1 & $0.628 *$ \\
\hline The amount of $\alpha$-amino $\mathrm{N}$ & - & - & 1 \\
\hline \multicolumn{4}{|c|}{ Correlation matrix for genotype Otis } \\
\hline Number of leaves & 1 & $0.801^{* *}$ & $-0.362^{\mathrm{ns}}$ \\
\hline The leaf area & - & 1 & $0.001^{\mathrm{ns}}$ \\
\hline The amount of $\alpha$ - amino $\mathrm{N}$ & - & - & 1 \\
\hline \multicolumn{4}{|c|}{ Correlation matrix for genotype Chiara } \\
\hline Number of leaves & 1 & $0.770 * *$ & $-0.724 *$ \\
\hline The leaf area & - & 1 & $0.629 *$ \\
\hline The amount of $\alpha$ - amino $\mathrm{N}$ & - & - & 1 \\
\hline \multicolumn{4}{|c|}{ Correlation matrix for genotype Laetitia } \\
\hline Number of leaves & 1 & $0.990 * *$ & $0.418^{\mathrm{ns}}$ \\
\hline The leaf area & - & 1 & $0.405^{\mathrm{ns}}$ \\
\hline The amount of $\alpha$ - amino $\mathrm{N}$ & - & - & 1 \\
\hline \multicolumn{4}{|c|}{ Correlation matrix for genotype Irina } \\
\hline Number of leaves & 1 & $0.485^{\mathrm{ns}}$ & $0.197^{\mathrm{ns}}$ \\
\hline The leaf area & - & 1 & $0.133^{\text {ns }}$ \\
\hline The amount of $\alpha$ - amino $\mathrm{N}$ & - & - & 1 \\
\hline \multicolumn{4}{|c|}{ Correlation matrix for genotype Severina } \\
\hline Number of leaves & 1 & $0.361 * *$ & $0.057^{\mathrm{ns}}$ \\
\hline The leaf area & - & 1 & $0.219^{\mathrm{ns}}$ \\
\hline The amount of $\alpha$ - amino $\mathrm{N}$ & - & - & 1 \\
\hline
\end{tabular}


The quality of sugar beet is complex characteristic, caused by genetic differences between varieties and diverse environmental conditions in the area of cultivation (Rosso and Candolo, 2001). In all cultivated plants there is interaction between genotype (variety) and external environment (Čačić et al., 1997, Pejić et al., 2010, Kolarić et al. 2015).

Sugar beet, in addition to its adaptability to climatic conditions, reacts quickly to changes in meteorological factors which greatly affect root yield and sugar content. For a good yield it requires a mean temperature of 15.3 to $16.4{ }^{\circ} \mathrm{C}$ (Bojović et al. 2014). Klenter et al. (2006), in their experiments, found that the optimum for plant growth is at $18{ }^{\circ} \mathrm{C}$. The high temperatures in July and August reduced the yield, but, at the end of season plant growth is not dependent on thermal conditions.

Surplus moisture in the air leads to a decrease in transpiration and productivity and, in the period of technological maturity, a negative impact on the accumulation of sugar. Great need sugar beet has in water, which provides over $3 / 4$ of its yield. For successful production, optimal amount of rainfall is 600 $\mathrm{mm}$, although irrigation significantly increased the root yield (Bojović et al. 2014).

Drought is a major limiting factor in sugar beet yields in many areas. Varieties with increased tolerance to drought can partially mitigated the harmful consequences of drought. These varieties have certain genotypic and phenotypic characteristics. Genotypic characteristics is the root system with a larger absorption surface, more developed palisade tissue, thicker cuticle, fewer stomata, higher content of bound water, more osmotic active substances and the like. From phenotypic characteristics should be noted that these varieties have larger leaves shine, greater turgescence in petioles and leaflets, easily breakable leaves and susceptible to stretching. Particularly important is the rapid growth in the spring of these plants because if a drought occurs in the early stages of growth of root growth is slowing down, which can lead to yield losses of up to $46 \%$, while in the later stages of the growth this loss is less significant. Proper protection of crops is very important for a good sugar beet yield. Proper protection is use of chemical preparates on seeds and young plants. In the area of South Banat (where experiments are performed) recorded the presence of 160 weed species (Nestorović, 2009). Suppression of herbicides is justified only if they achieve high yield (Ivanović et al. 1999). The most common diseases on sugar beet causing pathogens Cercospora and Rhizomania with which must be combated with chemical preparations. In the absence of chemical treatment of the foliage can be completely collapse, leading to a complete loss of yield. Attack of the parasites can reduce 1-2\% of sugar content in the roots (Kuzevski et al. 2008, Bojović et al. 2014). Soil characteristics influence nutrient solubility, but also microbial activity and root growth (Knežević et al. 2009, 2014).

The proper selection of varieties for a particular production area contributes to greater and more stable production of cultivated plants. In order to cost-effective production and processing of sugar beet cultivation it is reasonable 
to saw varieties in all three main directions of selection: Z (high content of sugar), $\mathrm{N}$ (normal) and $\mathrm{E}$ (high yield). The proposed manufacturing process for beet varieties share in the total sowed surface should be: $20 \% \mathrm{Z}, 50 \%$ of $\mathrm{N}$ and $30 \% \mathrm{E}$ type, but each manufacturer must be free to determine the basis of its own organizational and economic opportunities (Bojovic et al. 2014).

\section{CONCLUSIONS}

Based on the results obtained in this research can be done the following conclusions:

- The highest leaves number were formed at the genotype Otis, both individually and overall average, while the lowest leaves number have a genotype Severina. The variation in the number of formed leaves per nutrition variants was highest in genotype Laetitia and lowest at the genotype Otis.

- The largest leaf area, in total and individual average had genotype Otis and lowest values of this parameter had the genotype Severina. Variations in leaf area was the highest at genotype Leatitia and smallest in the genotype Severina.

- Indicator of root technological quality, amount of $\alpha$-amino $\mathrm{N}$, was the largest individually and in overall at the genotype Irina, while the lowest individual value had Chiara. The lowest average of amount of $\alpha$-amino $\mathrm{N}$ had Chiara and Laetitia (2.33 mmol / 1000S). Difference between the largest and smallest average amount of $\alpha$-amino $\mathrm{N}$ was highly significant (around $160 \%$ ).

- Based on the strength of the connection between the studied indicators, we can conclude that there was a correlation connection of all indicators, but of different intensity. Very strong positive correlation was between the number of leaves and leaf area $(r=0.828)$ and between the leaf surface and $\alpha$-amino $N(r=$ 0.628 ) in average for all examined genotypes.

\section{ACKNOWLEDGMENTS}

This study was supported by the Ministry of Education, Science and Technological Development of the Republic of Serbia, and was created as a result of the projects: TR 31025 and TR 31078 and bilateral projects (Montenegro and Serbia; 2019-2020): “Alternative cereals and oil crops as a source of healthcare food and an important raw material for the production of biofuel“".

\section{REFERENCES}

Bojović, R. (2014). Morphological and production characteristics of sugar beet in the conditions of intensive feeding plants. Doctoral dissertation. Faculty of Agriculture, Belgrade. 10-70.

Bojović, R., Glamočlija, Đ., Popović, V., Popović, B., Filipović, V., Kuzevski, J. (2014): Sugar beet yield parameters on carbonate chernozem soil type. Agriculture and Forestry. Podgorica. 60, 3: 41-53.

Čačić N., Kovačev, L. Mezei, S., Sklener, P. (1997): The interaction genotype environment on production characteristics of sugar beet. Plant breeding and Seed. Novi Sad. 4, 1-2, 127-134. 
Dobrovnaya, O.V., Tishalenko, E.N., Sakai, V.D, Chungunkova, T.V., Lyalao, I.I. (2009): Use of Biotechnical methods for increasing sugar content and tolerance of sugar beet to stress factors of environment collected scientific work of Nikita. Botan. Gard. p. 202-206.

Djekić, V., Popović, V., Branković, S., Terzić, D., Đurić, N. (2017): Grain yield and yield components of winter barley, Agriculture and Forestry, 63 (1): 179-185. DOI: 10.17707 / AgricultForest.63.1.21

Đekić, V., Popović, V., Jelić, M., Terzić, D., Branković, S. (2017): Effect of different doses of nitrogen fertilization on yield of winter wheat. Proceedings of the Journal of Institute of PKB Agroekonomik. 23, 1-2, 105-112.

Filipović, V., Glamočlija, Đ., Jaćimović, G. (2007): The influence of vegetation areas on yield and quality of different varieties of sugar beet. Proceedings. III Symposium with international participation, Agro-innovations in crop and vegetable production", Belgrade, 136-138.

Filipović, V., Glamočlija, Đ., Radivojević, G. (2009): Effects of crop density and harvesting time on yield and quality of different varieties of sugar beet. Plant breeding and Seed. Novi Sad. 25, 1. 45-53.

Ghasemi, A.R., Golparvar A. R. and Isfahani M. N. (2014). Analysis of genetic diversity of sugar beet genotypes using random amplified polymorphic DNA marker. Genetika, Vol 46, No. 3, 975-984.

Glamočlija, Đ. (1986): Effect of nitrogen and planting density on the productivity of photosynthesis and sugar beet yields. Doctoral dissertation. Faculty of Agriculture, Belgrade. 1-24.

Glamočlija, Đ. (1990): The impact strength of fertilization and plant density on yield and quality of sugar beet. PKB INI,, ",, IV Winter Seminar on Agriculture - farmers Serbia", Subotica, 5-9.02.1990. Proceedings, pp. 148-158.

Ivanović, M., Marković S., Kuzevski J., Krstanović, S. (1999): Efikasnost herbicida pri primeni pre i posle nicanja šećerne repe. XIII Savetovanje agronoma, veterinara i tehnologa, Aranđelovac, 5, 1-5.

Klenter, CH., Hoffman, M., Christa, Mailander, B. (2006): Effects of weather varialites on sugar beet yield development (Beta Vulgaris L). European Journal of Agronomy vol. 24, 1, 62-69.

Kolarić LJ., Gujaničić T., Živanović LJ., Ikanović J., Popović V. (2015). Uticaj sorte i roka vađenja na prinos i kvalitet šećerne repe. XXIX Savetovanje agronoma, veterinara i tehnologa, Institut PKB Agroekonomik, Beograd, 65-70.

Knezević, M., Perovic, N. Radulovic, M. Topalovic, A. (2009). Monitoring of soil fertility and Montenegro. 12th Congess of Society of Soil Science of Serbia Status and prospectives of Soil Protection Management and Use, Novi Sad, 148149.

Knežević, M., Đurović, D., Mugoša, B., Strunjaš, M., Topalović, A. (2014): Relationships between parameters of soil and chard (Beta vulgaris L. var. Ciclo L.). Agriculture \& Forestry, Vol. 60, Issue 3, 275-283.

Kuzevski, J., Krstanović, S., Šurlan-Momirović, G., Živanović, T., Jeličić, Z. (2008): The effect of mineral nutrition on the chemical composition of the sugar beet root. Conventional and molecular breeding of field and vegetable crops. Novi Sad, November 24-27, 609-612.

Maksimović L., Popović V., Stevanović P. (2018). Water and irrigation requirements of field crops grown in central Vojvodina, Serbia. Agriculture and Forestry, Podgorica, 64, 1, 133-144. DOI: 10.17707 / AgricultForest.64 
Nenadić, N., Nedić, M, Živanović, LJ., Kolarić, LJ., Gujaničić, T. (2003): Effect of genotype on sugar beet yield and quality. Journal of Agricultural Sciences. 48, 1, $1-9$.

Nestorović, M. (2009): Korovska flora Pančevačkog rita. Savremena poljoprivreda, 58, $1-2,1-11$.

Ninfale, P. \& Angelino D. (2013): Nutritional and functional potential of Beta vulgaris cicla and rubra. Fitoterapia 89: 188-199.

Pejić, B., Maksimović L., Milić, S., Rajić, M. (2010): Effect of irrigation and nitrogen fertilization on yield and productivity of sugar beet. Modern Agriculture. Novi Sad. 59, 1-2, 45.

Rosso, F., Candolo, G. (2001): Evaluation of sugar beet main quality features through the analysis of the diffusion juices produced by y pilot plant. 64. IIRB Congress, Bruges, Belgium, 26-27 Jun 2001, vol. 64, pp. 437-442.

Stevanović P., Popović V., Jovović Z., Ugrenović V., Rajičić V., Popović S., Filipović V. (2018): Quality of wheat seed in relation to fragment and feeding locality. Proceedings of the Institute PKB Agroekonomik, 24, 1-2, 65-74.

Terzić D., Popović V., Radović J., Marković J., Milenković J., Vasić T., Filipović V. (2017): The influence of combining crops and the method of sowing on the energy and protein value maize and soybean in the second sowing. Journal of Institute PKB Agroeconomic, Belgrade, 23, 1-2, 20-27.

Trifunović, S., Topalović, A., Knežević, M., Vajs, V. (2015): Free radicals and antioxidants: antioxidative and other properties of Swiss chard (Beta vulgaris L. subsp. Cicla). Agriculture and Forestry, Podgorica. 61, 2: 73-92.

Ugrenović V., Bodroža Solarov M., Pezo L., Đisalov J., Popović V., Marić B., Filipović V. (2018): Analysis of spelt variability (Triticum spelta L.) grown in different conditions of Serbia by organic conditions. Genetika, Belgrade. 50, 2, 635-646.

Živanović Lj, Savić J., Ikanović J., Kolarić Lj., Popović V., Novaković M. (2017). The influence of genotype on wheat, soybean, corn and sunflower grain yield. Proceedings of the Institute of PKB Agroekonomik. Belgrade. 23, 1-2, 39-49. 